\title{
1. INTRODUCTION: BACKGROUND AND EXPLANATORY NOTES, DEEP SEA DRILLING PROJECT LEG 85, CENTRAL EQUATORIAL PACIFIC ${ }^{1}$
}

\author{
Shipboard Scientific Party ${ }^{2}$
}

\section{BACKGROUND}

Since the inception of the Deep Sea Drilling Project (DSDP), the central equatorial Pacific has been a primary target for oceanic drilling. Four DSDP legs have drilled in this region (Legs 5, 8, 9, and 16; Fig. 1), and the materials and data recovered by this drilling, as well as by numerous other programs, have been instrumental in establishing global Tertiary tropical biostratigraphy and chronology, in shaping our understanding of past oceanographic events, and in the development of tectonic models for the Pacific Plate. Beginning with such pioneering investigations as Arrhenius (1952), Bramlette (1961), Riedel and Funnell (1964), Hays et al. (1969), Hays et al. (1972), Berger (1973), and Winterer (1973), hosts of studies have demonstrated that Tertiary equatorial sediments are sensitive recorders of the interplay between tectonism, oceanic circulation patterns, biological productivity, dissolution, and diagenesis. Foremost among this research is the synthesis of the Cenozoic history of the equatorial Pacific by van Andel et al. (1975), which is largely based on DSDP results. Despite this wealth of information, the conduct of fine-scale research in sediments beyond the reach of conventional piston coring has been hampered by drilling disturbance. The disturbance is especially troublesome in the unconsolidated sediments in the upper 100 to $300 \mathrm{~m}$ of the sediments, which often comprise much of the Neogene.

When DSDP developed the hydraulic piston corer (HPC), it became possible to recover fairly undisturbed samples from the upper 100 to $300 \mathrm{~m}$ and thus to carry out high resolution stratigraphic studies. DSDP Leg 85 was designed to take advantage of this capability. A modified HPC (the VLHPC-variable length hydraulic piston corer) and rotary coring were to be used to recover complete, undisturbed equatorial Pacific sections.

\footnotetext{
${ }^{1}$ Mayer, L., Theyer, F., et al., Init. Repts. DSDP, 85: Washington (U.S. Govt. Printing Office).

2 Larry Mayer (Co-Chief Scientist), Dalhousie University, Halifax, Nova Scotia, Canada: Fritz Theyer (Co-Chief Scientist), Hawaii Institute of Geophysics, University of Hawaii, nia); John A. Barron, U.S, Geological Surver, Menlo Park, California; Dean A. Dunn, University of Rhode lsand, Neological Survey, Menlo Park, California; Dean A. Dunn, Univississippi, Mississippi, Hattiesburg, Mississippi); Tim Handyside, The University, Newcastle upon Tyne,
United Kingdom; Scott Hills, Scripps Institution of Oceanography, La Jolla, California; Ian Jarvis, City of London Polytechnic, London, United Kingdom (present address: Kingston Polytechnic, Kingston-upon-Thames, United Kingdom); Catherine A. Nigrini, La Habra Heights, California; Nicklas G. Pisias, Oregon State University, Corvallis, Oregon; Annick Pujos, Université de Bordeaux, Talence, France; Tsunemasa Saito, Yamagata University, Yamagata, Japan; Paul Stout, Scripps Institution of Oceanography, La Jolla, California; Ellen Thomas, Scripps Institution of Oceanography, La Jolla, California (present address: ( Geological Obervik, Colu stitut für Geophysik, Ruhr Universität Bochum, Bochum, Federal Republic of Germany; and Roy H. Wilkens, Massachusetts Institute of Technology, Cambridge, Massachusetts.
}

The biostratigraphy, magnetostratigraphy, and seismic, carbonate, and stable isotope stratigraphy of these sections were to be studied to develop a better understanding of the paleoceanographic and paleoclimatic history of the region.

The JOIDES Ocean Paleoenvironment Panel selected five drill sites that would best address the Leg 85 objectives within the constraints of available ship time. Two sites (571 and 572) are in the eastern Pacific, and the three others $(573,574$, and 575$)$ form a north-south line that lies at approximately $133^{\circ} \mathrm{W}$ across the equatorial high productivity zone (Fig. 1). The operational plan was to piston core each site twice (to ensure the recovery of a complete section) and then to use rotary coring to drill to basement through the stiffer sediments below the reach of the VLHPC. The drilling at all five sites was expected to result in the recovery of "reference" sections for the study of foraminifers, nannofossils, radiolarians, diatoms, and other fossils. Except at Sites 571 and 572, where basement age was known to be Miocene (Site 572 repeats Site 81, Leg 9), the basement age at all the sites was expected to be latest Eocene. Therefore, we hoped to recover complete or nearly complete records of the Eocene-Oligocene transition.

A secondary objective was to make a detailed examination of the relationships between paleoceanographic changes and the acoustic and physical properties of the sediments. Understanding these relationships could substantially increase the ability to use seismic stratigraphy as a paleoceanographic tool. Because such studies must be made in undisturbed sediments, however, they have been restricted in the past to the penetration depth of standard piston cores (10 to $20 \mathrm{~m}$; Mayer, 1979a, b; Embley and Johnson, 1980). During Leg 85, the VLHPC would allow us to extend this research to sub-bottom depths of about $200 \mathrm{~m}$ and thus to evaluate variations in the factors that control acoustic properties as far back as the early to middle Miocene.

Another secondary objective was to conduct an in situ heat flow and pore water experiment to study pore water advection in a region of unusually low heat flow (Site 571).

\section{THE VARIABLE LENGTH HYDRAULIC PISTON CORER}

In December 1978 the Deep Sea Drilling Project deployed the first hydraulically actuated wireline piston corer (HPC). This coring system, which is described in Prell, Gardner, et al. (1982), operates on a hydraulic piston principle. Fluid pumped through the drill pipe acti- 


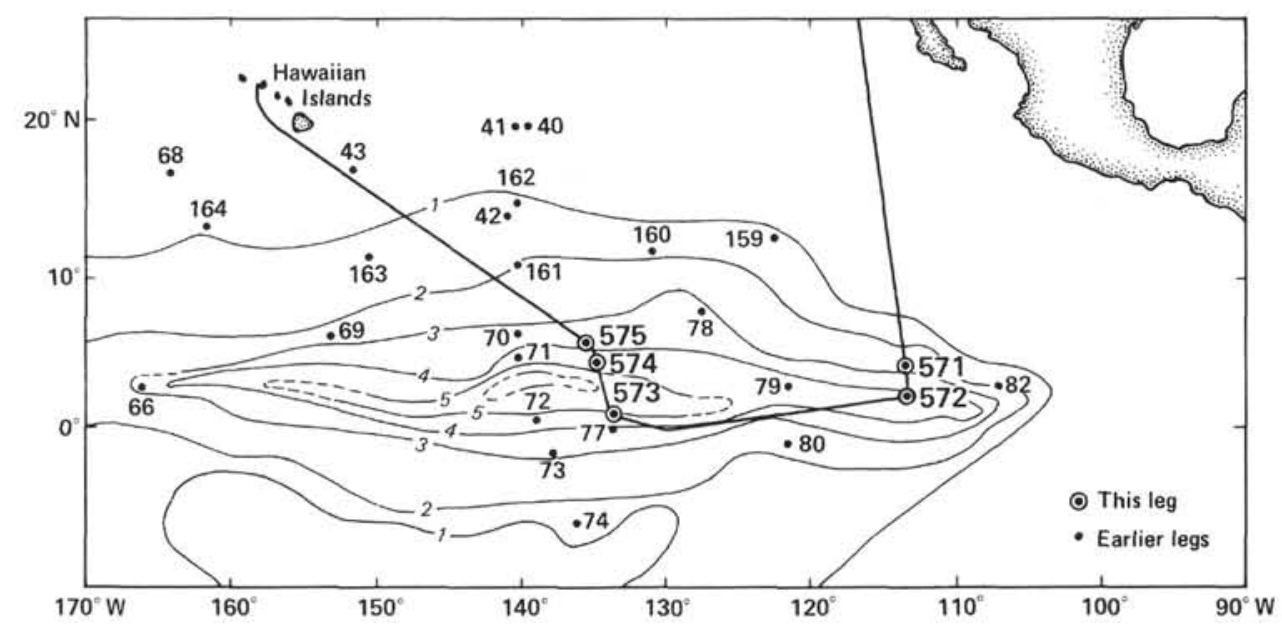

Figure 1. Cruise track and site locations of Leg 85 in relation to acoustic sediment thickness (contours in tenths of seconds of two-way traveltime) and previous DSDP drill sites (Legs 5, 8, 9, 16). Acoustic stratigraphy from Ewing et al. (1968).

vates a piston-driven core barrel, which is ejected through the core bit into the sediment at the rate of approximately $60 \mathrm{~m} / \mathrm{s}$. Because of this extremely high penetration rate, the motion of the core barrel is decoupled from the motion of the drill string. After each coring operation, the core barrel assembly is retrieved by wireline, as in a conventional coring operation. The drill bit is then "washed down" to the next coring point, where the piston coring procedure is repeated.

Since Leg 80 (May 1981), the improved coring system referred to as the variable length hydraulic piston corer has been in use (Fig. 2). The VLHPC is capable of recovering cores up to $9.5 \mathrm{~m}$ in length, whereas the HPC could recover cores of only $4.5 \mathrm{~m}$. On Legs 80 to 86 , recovery with the VLHPC has averaged more than $93 \%$, with some holes achieving $100 \%$.

The VLHPC recovers core in a standard $(6.6 \mathrm{~cm}$ inner diameter) butyrate core liner. The drill bit used is a special 11.5 in. outer diameter roller cone drill bit with a 3.62 in. core throat. Coring must be discontinued when the sediments become too indurated. On Leg 85 the factor that limited the use of the VLHPC was not the shear strength of the sediment, however. The maximum shear encountered was $700 \mathrm{~g} \mathrm{~cm}^{-2}$, and the HPC has successfully penetrated sediment with a shear strength of 1200 $\mathrm{g} \mathrm{cm}^{-2}$. On Leg 85 drilling in many holes terminated because of the loss of the lower core barrel assembly as a result of the excessive force (overpull) necessary to remove the core barrel from the sediment. When overpull exceeded about 15 to 25 tons, the quick release on the core barrel failed, leaving the lower barrel in the mud. This meant abandoning the hole, although not tripping the pipe, for continued coring.

The intervals of excessive overpull (Fig. 3), although often deeper than about $150 \mathrm{~m}$, showed no obvious correlation with age, depth, lithology, or shear strength. This intriguing and bothersome distribution made coring difficult to plan. When we encountered excessive overpull with the $9.5 \mathrm{~m}$ core barrel, we switched to the $5 \mathrm{~m}$ barrel, but even the shorter barrel was subject to excessive forces, and several of them were lost.

\section{HEAT FLOW EXPERIMENTS}

The use of heat flow probes in drill holes has been described by Erickson et al. (1975); von Rad, Ryan, et al. (1979); and Uyeda et al. (1982). Leg 85, however, was the first leg to use the heat flow tool in conjunction with the VLHPC (at Site 571). Unfortunately, the tool did not seat properly. The landing subassembly in the heat flow assembly landed on top of the piston corer seal sleeve, allowing seawater to bypass the seals and contaminate the heat flow and pore water measurements. By the time the problem was corrected we had time for only one more run, and the data were lost as a result of electronic problems. At Site 573 we attempted another heat flow measurement. This time the sandline parted while the sampler was being retrieved. The instrument was not damaged, and the pore water data obtained were valid, but the heat flow data were questionable.

\section{BIOSTRATIGRAPHIC TIME SCALE}

The Leg 85 biostratigraphic time scale (Fig. 4) incorporates the planktonic foraminiferal zones of Blow (1969), the calcareous nannofossil zones of Bukry (1975) with notation after Okada and Bukry (1980), the radiolarian zones of Nigrini (1971) and Riedel and Sanfilippo (1978), and the diatom zones of Burckle (1972) and Barron (in press and this volume). Calibration of microfossil datum levels to paleomagnetic stratigraphy follows Saito et al. (1975), Burckle $(1972,1978)$, Theyer et al. (1978), Haq et al. (1980), Vincent (1981), Poore et al. (1984), Berggren et al. (in press), and Theyer (unpubl. data). The absolute ages and the sequence of anomalies in the paleomagnetic time scale follow Berggren et al. (in press), and epoch and subepoch boundaries are after Van Couvering and Berggren (1977), Berggren (1983), and Berggren et al. (in press). Cross correlation of microfossil zones and subzones was adjusted slightly after study of Sites 572 to 575 .

For an updated version of the time scale incorporating more information from shore-based research, see Barron et al. (this volume). 


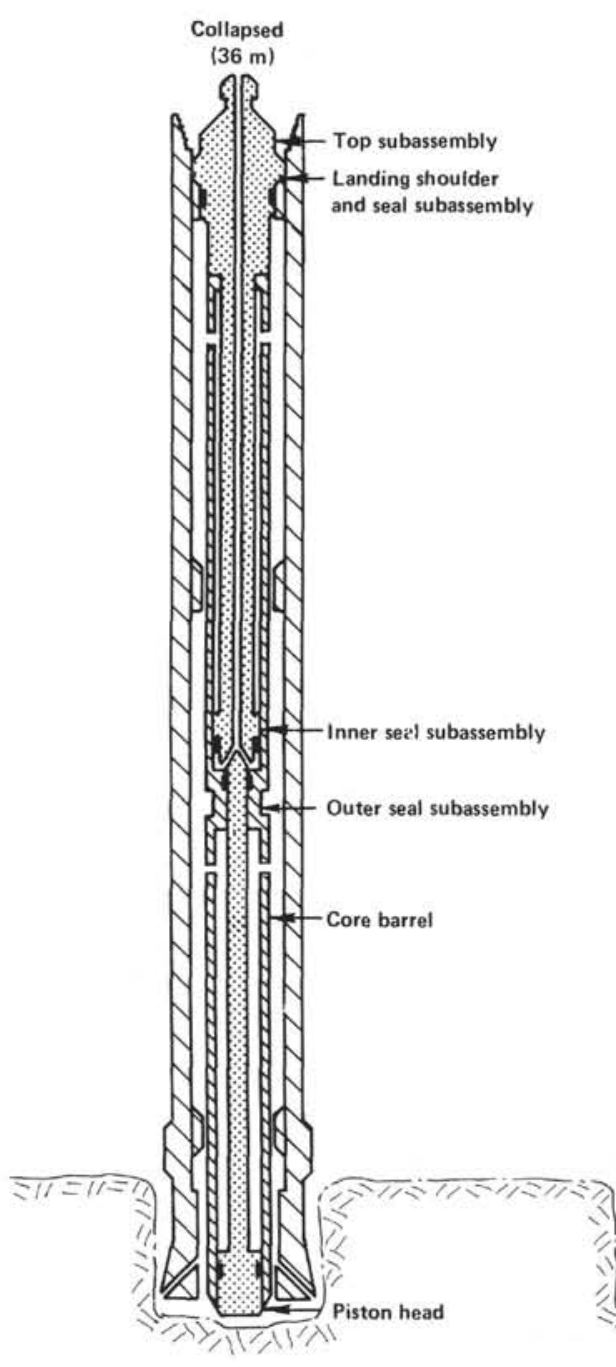

Extended

賠

Piston corer is seated and seawater is pumped at $350 \mathrm{gal} / \mathrm{min}$. to initiate action.

Locking pins shear at a maximum of 2800 psi.

The outer seal subassembly then drives the core

barrel into the formation as fluid above

the piston head is vented.

3

At the end of the stroke damping

ports are uncovered, which vent the

pressure fluid and decelerate the core

barrel.

\section{4}

Rig floor sees drop in pump pressure as an indication that the corer has fully stroked.

Core barrel is retrieved. Bit is washed down to next coring point. Process is repeated until formation becomes too indurated.
Figure 2. Variable length hydraulic piston corer.

In this volume, the use of Ma follows that advocated by Berggren et al. (1976).

\section{SEDIMENT ACCUMULATION RATES}

Sedimentation rates for all sites occupied on Leg 85 were calculated by using the biodatums listed in Table 1 . Almost all of the datums have been correlated directly to the magnetic reversal stratigraphy (see Table 1 for references).

Sedimentation rate curves were constructed for each site by plotting the estimated age range for each corecatcher sample versus sub-bottom depth. The sedimentation rate curve was taken as the fewest number of straight-line segments that passed through all age range estimates. In each site chapter only the sedimentation rate curves are shown (not the data); however, each curve except that for Site 571 was defined from at least 30 data points.

Mean mass accumulation rates were calculated within the intervals of constant sedimentation rates. The accumulation rates for the total sediment, as well as the calcium carbonate and carbonate-free fraction, were calculated by using the mean bulk density and calcium carbonate values calculated for each interval.

\section{CLASSIFICATION OF SEDIMENTS}

The sediments are classified according to the types and proportions of their components. Component proportions are determined from smear slide observations and expressed as percentages. The terms used for (and definitions of) relative abundances are trace amounts (less than $1 \%$ ), rare (1 to $5 \%$ ), common (5 to $25 \%$ ), 


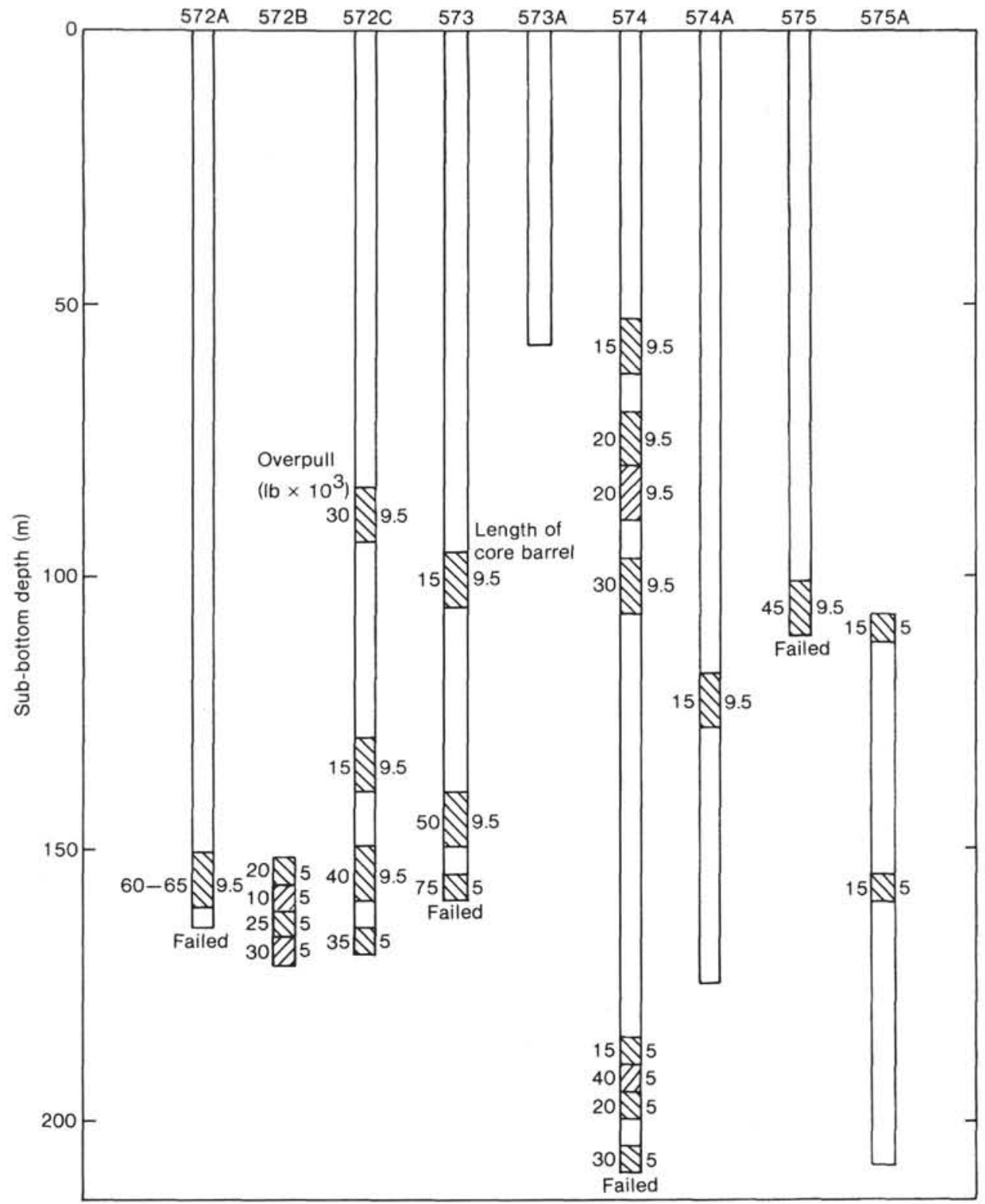

Figure 3. Intervals of excessive overpull.

abundant ( 25 to $75 \%$ ), and dominant (greater than $75 \%$ ). The percentages are estimates of areal abundances in the smear slides and may differ from the more accurate laboratory analyses of grain size, carbonate content, and mineralogy. Experience has shown that distinctive minor components can be estimated accurately ( \pm 1 to $2 \%$ ) but that an accuracy of $\pm 10 \%$ is all that can be expected for major constituents. Carbonate content is especially difficult to estimate in smear slides, as is the amount of clay-sized material present. Since Leg 85 examined pelagic sediments from the equatorial region almost exclusively, we used a classification scheme intended to emphasize recognizable differences in biogenic components (Fig. 5).

\section{Descriptive Data}

Figure 5 shows the categories into which the sediments are classified. If an individual component (cal- careous nannofossils, foraminifers, radiolarians, diatoms, or pelagic nonbiogenic material) makes up more than $10 \%$ of the sediment, that component is included in the formal name of the sediment. If several components are present in amounts greater than $10 \%$, they are listed in order from most to least abundant, up to a maximum of four names. For example, a sediment composed of $15 \%$ radiolarians, $25 \%$ foraminifers, and $55 \%$ nannofossils would be called a radiolarian foraminiferal nannofossil ooze. If a combination of either siliceous or calcareous components makes up more than $10 \%$ of a sediment, but no single component itself constitutes $10 \%$, the modifier calcareous or siliceous is used in the name. For example, a sediment composed of $7 \%$ radiolarians, $6 \%$ diatoms, and $87 \%$ nannofossils is called a siliceous nannofossil ooze. The modifier calcareous is also used if more than $10 \%$ of the sediment consists of unrecognizable carbonate components. 


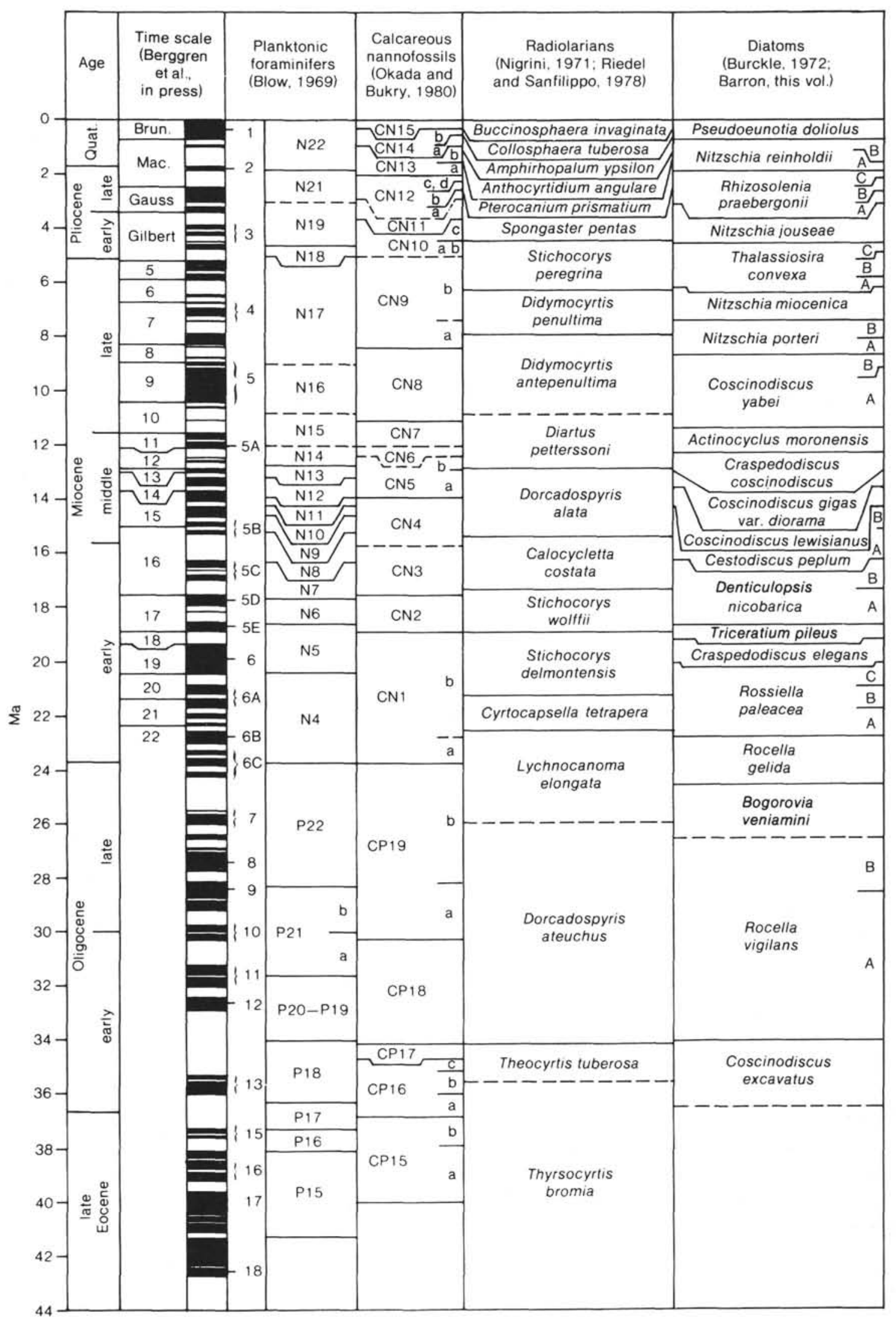

Figure 4. Biostratigraphic time scale adopted for DSDP Leg 85 . 


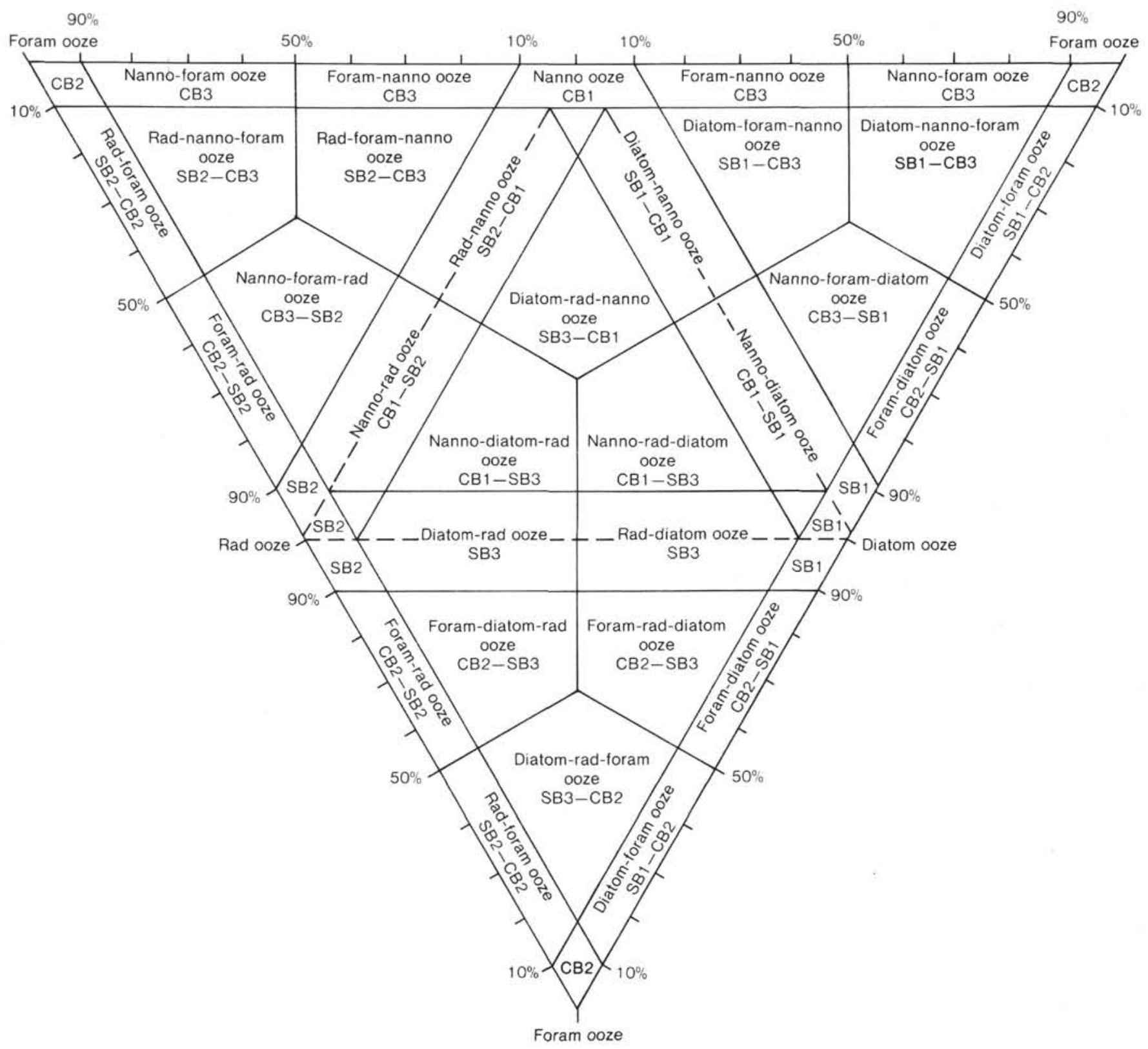

Figure 5. Sediment classification categories used in DSDP Leg 85. For an explanation of the codes, see Figure 10.

Grain-size boundaries between sand-silt and silt-clay are those described by Wentworth (1922). The grain-size estimates are probably accurate within 20 to $30 \%$. The size of many of the nannofossils is about $4 \mu \mathrm{m}$, which defines the silt/clay boundary. Breakage of larger grains (foraminifers and radiolarians) during smear slide preparation probably accounts for the limited reliability of the grain-size estimates.

\section{Induration of Sediments}

Determinations of induration are highly subjective, but field geologists have successfully made such distinctions for years. Our criteria are described below. The criteria for calcareous ( $50 \%$ carbonate) sediments are those of Gealy et al. (1971). The criteria for other sediments are based on subjective estimates of behavior in corecutting.

Calcareous sediments. Oozes have little strength and are readily deformed under the finger or the broad blade of a spatula. Chalks, which are partly indurated oozes, are friable and readily scratched with a fingernail or the edge of a spatula blade. Limestones are cemented and resistant to scratching.

Siliceous sediments. Oozes are as above. Cherts are impossible to scratch and must be cut with a diamond saw.

Other sediments. If the material is soft enough for the core to be split with a wire cutter, only the sediment name is used (e.g., silty clay, sand). If the core has to be sawn, the suffix "stone" is added (e.g., claystone, sandstone). 


\section{CLASSIFICATION OF IGNEOUS ROCKS}

The few sections of igneous rock recovered were classified by visual inspection only. No thin sections were studied on board ship.

\section{SHIPBOARD PALEOMAGNETIC STUDIES}

The paleomagnetism of samples selected from all holes was measured on board. The sampling intervals, normally 30 to $50 \mathrm{~cm}$, were adjusted according to drilling disturbance and the intensities encountered (few or no samples were taken in intervals with intensities in the range of the noise level of the magnetometer). The untreated natural remanent magnetization $\left(\mathrm{NRM}_{0}\right)$ was measured with a Digico spinner magnetometer and calibrated against a shipboard standard. The calibration was checked at least once per hour, and intensity drift was found to be insignificant. The magnetometer was driven at $2^{7}$ or $2^{8}$ spins (depending upon the intensity), and the noise level of the instrument was on the order of $10^{-8} \mathrm{G}$.

An absolute azimuthal Kuster orientation device was used on the VLHPC to orient the core liner photographically with respect to magnetic north. Although it was difficult to read the photographic orientation slides (as a result of pre-trip flash failure and blurring), about $57 \%$ of the records contain reasonable data. Unfortunately, onshore paleomagnetic work showed that there are systematic downcore variations in the measured declinations, and these variations make it very difficult to correlate declination with azimuthal orientation. As an example, Figure 6 shows the variation of the declination data down Cores 4 and 5 of Hole 573. Whereas the marked (x) $180^{\circ}$ declination offsets are produced by reversals of the geomagnetic field, clockwise, as well as anticlockwise, variable rotations of different magnitude are clearly shown by the declination data. In Core 4 the gradient decreases with depth, and in Core 5 it almost stops at the lower part, being very high in the upper part. These are only a few of the possible kinds of rotation. The variations are expressions of relative motion between sediment, core liner, and possibly even the VLHPC barrel itself. Thus, if the Kuster system is usable at all, it most likely orients only the uppermost part of a twisted core, and a correction must be derived for the lower part. The device records the barrel's azimuthal orientation only once, just prior to coring, which is an unsatisfactory solution, given the multiple possibilities of the torsioning of the sediments during the coring itself. Systematic studies of these gear-induced rotations are necessary to obtain an idea of their magnitude and direction.

\section{INORGANIC GEOCHEMISTRY}

Samples were processed for the analysis of interstitial waters in the manner described by Gieskes $(1973,1974)$. Samples were refrigerated immediately after recovery until squeezing, which was done at room temperature. Samples from Hole 572, however, were taken after the core had reached thermal equilibrium with room temperature (approximately $10 \mathrm{hr}$.). Reactions during such ex-

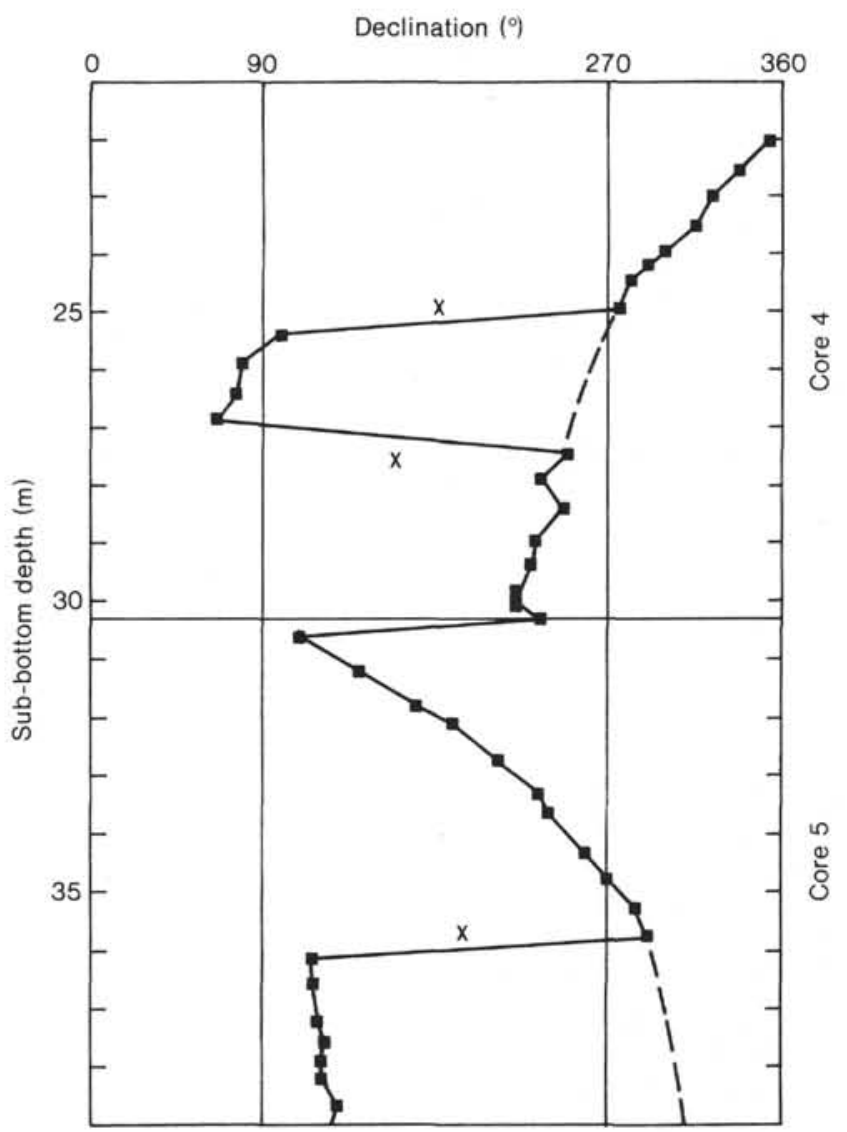

Figure 6. Downcore rotation $(\mathrm{x})$ of paleomagnetic declination data produced by VLHPC coring. Hole 573.

tended storage at room temperature greatly reduce the reliability of the data from Hole 572 .

Standard "Karbonat Bombe" shipboard techniques (as described by Müller and Gastner, 1971, and Dunn, 1980) were followed.

\section{MEASUREMENT OF PHYSICAL PROPERTIES}

Detailed measurements of physical properties were carried out at all sites. The experiments included the use of the gamma ray attenuation and porosity evaluator (GRAPE; Boyce, 1976a) to determine the saturated bulk density; the gravimetric determination of wet-bulk density and water content (Boyce, 1976a); and the measurement of sonic velocity (Boyce, 1976b), thermal conductivity (Von Herzen and Maxwell, 1959), electrical conductivity (Manheim and Waterman, 1974), and shear strength (Boyce, 1976b). The sampling interval was usually once per section $(1.5 \mathrm{~m})$ for all parameters, except for shear strength, which was measured once per core $(9.5$ or $5 \mathrm{~m})$ at Sites 574 and 575 . The sampling interval was generally halved in duplicate HPC sections where the first section had produced undisturbed sediments. In all cases, cores were allowed to reach thermal equilibrium before any physical properties were measured.

Thermal conductivity data were reduced from analog records at Site 572. At Site 573 and thereafter the Woods Hole Oceanographic Institution (WHOI) digital multi- 
probe measuring system was employed. A well-documented problem with the DSDP needle probe system used at Site 572 results in measurement values that are somewhat higher than those generally accepted for the area. At Site 573 both the DSDP and the WHOI instruments were used. A correction factor for the DSDP probes was calculated from these data and applied to the Site $\mathbf{5 7 2}$ results (Wilkens and Handyside, this volume).

The electrical conductivity measurements suffered from occasional shifts in the baseline values of indicated seawater conductivity. The shifts were not critical to the measurement, because the formation factor is a ratio of sediment-to-seawater resistivities. Thus, absolute values may be slightly less precise than hoped for, but they should still be within $10 \%$ of true values, which is acceptable in a parameter that varies over orders of magnitude for sediments.

Gravimetric and sonic velocity data were dependable at all sites. There was some scatter in the upper reaches of Site 572, possibly as the result of sampling technique. All the data were standardized quickly, however, and the results from all the sites are generally consistent.

\section{VISUAL DESCRIPTIONS}

\section{Coring Deformation}

The use of the VLHPC greatly reduced the amount of disturbance in cores of soft sediments. Nevertheless, the following four types of disturbance were found:

Wash-in. Wash-in occurs at the top (about $1 \mathrm{~m}$ ) of many cores and results from hole cave-in and bit motion. It is easy to recognize and does not represent a serious problem.

Liner collapse. The liners shattered occasionally, usually when we cored sediment with zones of alternating induration. Liner collapse causes severe disturbance, but it was infrequent on this leg.

Flow-in. Flow-in looks the same as it does in a standard piston core (Fig. 7). It occurs in the middle of cores and is usually bounded by sharp contacts with undisturbed sediment. The origin of flow-in is not understood, but it may be related to the lack of a breakaway piston in the VLHPC, the extreme vacuum generated by the pull-out process when the sediment does not completely fill the liner, and drill string motion.

O-rings. O-rings placed outside the liner often end up in the middle of the core. When the core is split, the splitting device drags the rings through the sediment. The problem is not serious, but it is annoying.

Mechanical disturbance in rotary-drilled sections is the result of the coring technique, which uses a large ( $25 \mathrm{~cm}$ diameter) bit with a small $(6 \mathrm{~cm}$ diameter) opening for the core samples. The following disturbance categories were used:

Slightly deformed. Bedding contacts are slightly bent.

Moderately deformed. Bedding contacts have undergone extreme bowing, and firm sediment is fractured.

Very deformed. Bedding is extremely disturbed or homogenized, and some sections show diapir-like structures and other fluidization phenomena.

Soupy. Sediment is saturated with water and has lost all aspects of bedding.
Breccia. Indurated sediment has been broken into angular fragments by the drilling process.

The categories above are designated in the core description forms (Fig. 8) by the symbols shown in the "Drilling Disturbance" column. In rotary-drilled sections, firm sediment may also be broken into "drill biscuits" that are enclosed in a breccia or soup. These sections are not automatically designated as very deformed; they are evaluated according to the degree of displacement shown by the undeformed biscuits.

Downhole contamination occurs when sediment falls, is dragged, or is washed to a lower stratigraphic interval and then cored. This material is generally recognized by its soupy character, contrasting color, and the younger fossils it contains. Where downhole contaminants are recognized, they are marked on the core descriptions.

\section{Sedimentary Structures}

In cores of oozes (and even some indurated sediments), it may be extremely difficult to distinguish between natural structures and structures created by the coring process. Identifiable megascopic sedimentary structures include graded bedding, cross bedding, bioturbation, microfaulting, and lamination. Where it is reasonably certain that these features are not the product of coring disturbance, they are logged graphically (with the symbols shown in Fig. 9) in the "Sedimentary Structures" column of the core description form.

Bioturbation, which often includes undeformed and identifiable burrow types, is a prominent feature of many cores recovered on Leg 85 . Where ichnogenera have been identified they are included in the core descriptions. The most important ichnogenera found are Planolites, Zoophycos, and Chondrites.

\section{Color}

The colors of the rocks were determined with a Munsell or Geological Society of America Rock-Color Chart immediately after the cores were split and while they were still wet.

\section{Graphic Lithology}

The graphic column on the core description form is based on the lithologies, which are represented by a single pattern or a grouping of two or more symbols (Fig. 10). The symbols in a grouping correspond to end-members of sedimentary constituents, such as clay or nannofossil ooze. The symbol for the clastic or authigenic components appears on the right side of the column, and the symbol for the biogenic constituents appears on the left side. The abundance of a component approximately equals the percentage of the width of the graphic column its symbol occupies. Since graphic lithologies represent average compositions derived from smear slides they do not, however, always reflect the detailed alternation of sediment types. Major lithologic boundaries are shown, but gradational contacts, small-scale cyclicity, and ooze-chalk alternations are represented schematically.

Because of the difference in length-to-width ratio between the actual core and the graphic lithology column it is not possible to reproduce structures as they appear 


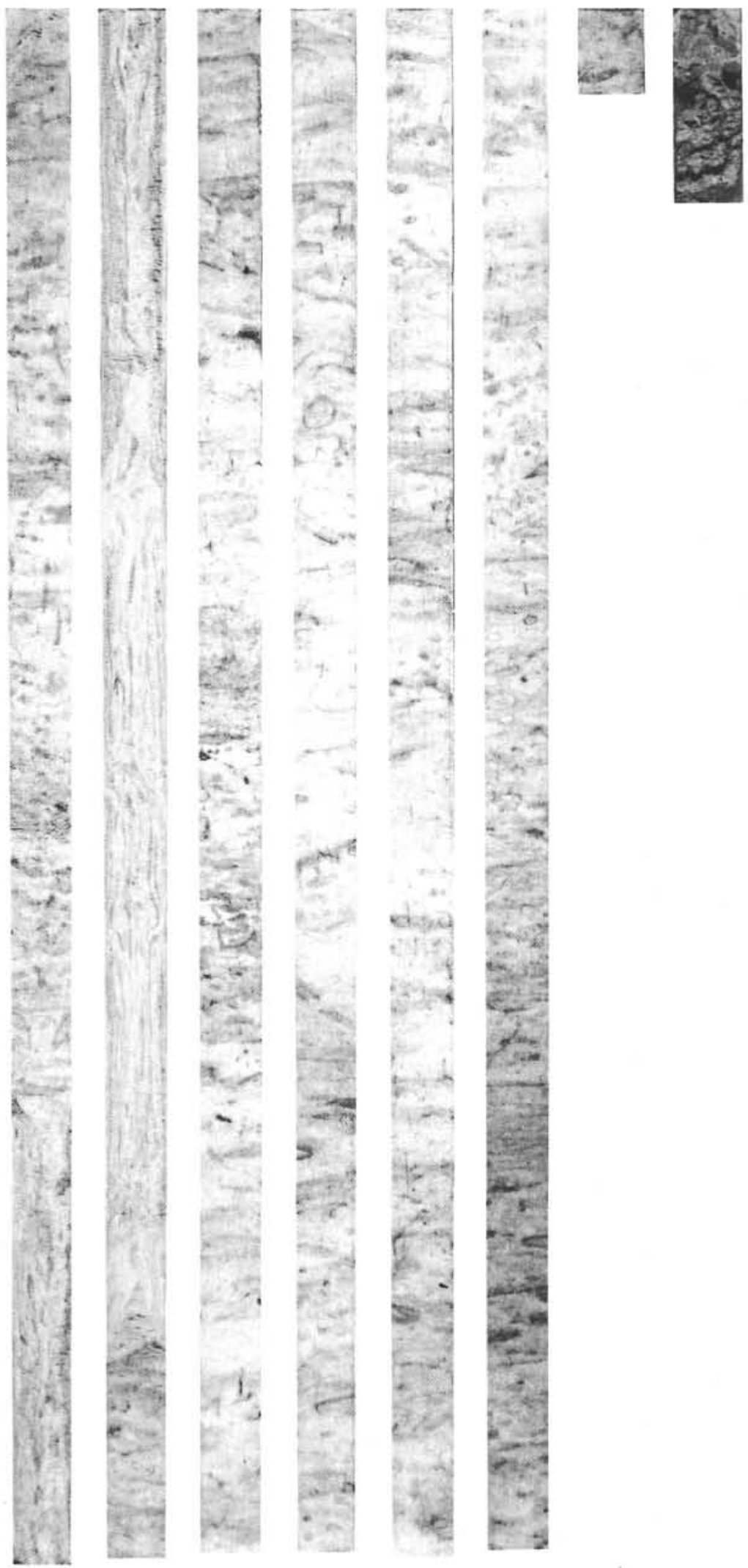

Figure 7. Flow-in in a VLHPC core (Section 2). Note the sharp contacts between disturbed and undisturbed sediments. Hole 572A, Core 13,109.9 to $119.1 \mathrm{~m}$ sub-bottom. 
SHIPBOARD SCIENTIFIC PARTY

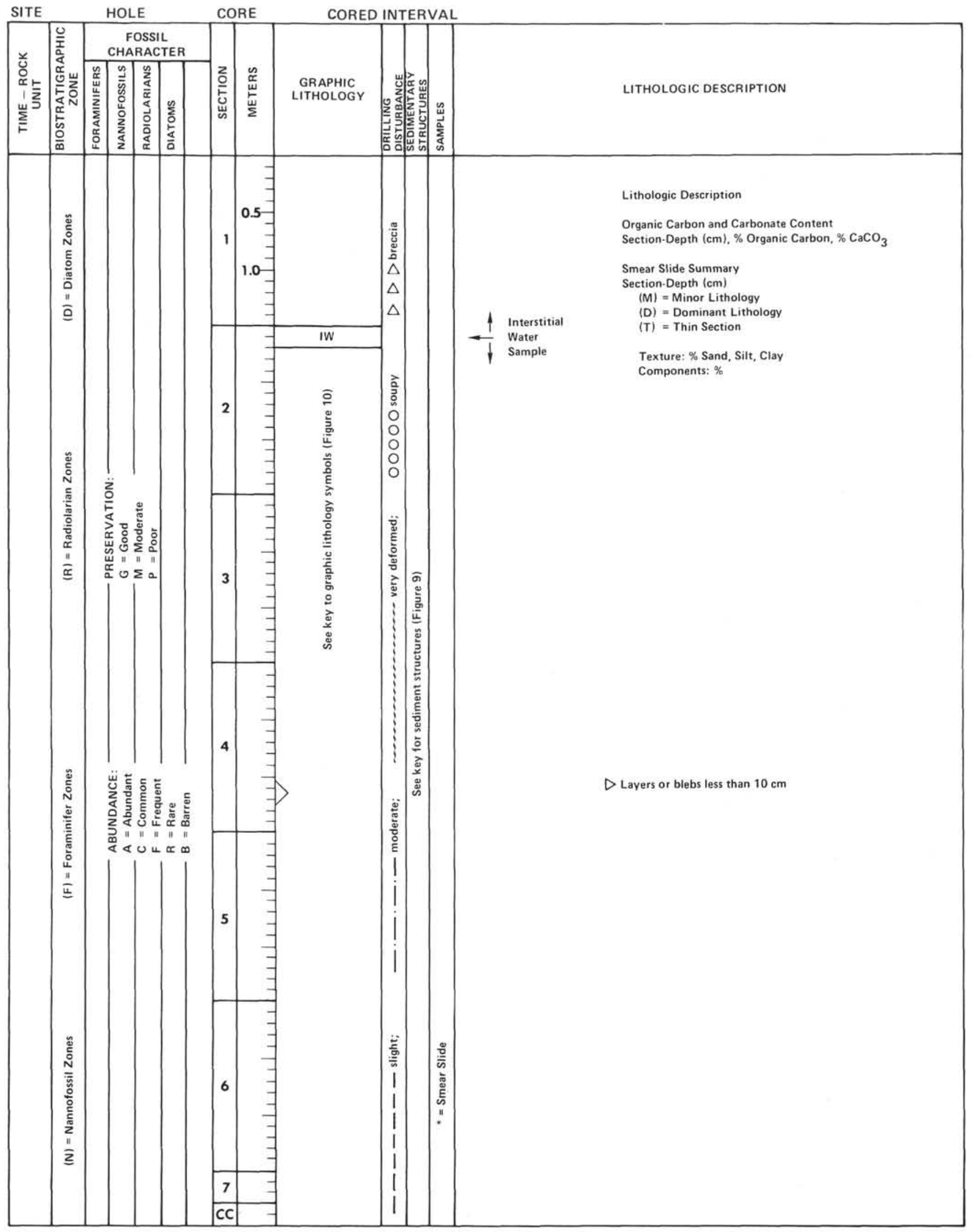

Figure 8. Sample core description form.

14 


\begin{tabular}{|c|c|}
\hline & Parallel laminations \\
\hline गПगП, & Cross stratification \\
\hline$\cdots$ & Normal graded bedding \\
\hline & Sharp contact \\
\hline$\cdots$ & Scoured, sharp contact \\
\hline---- & Gradational contact \\
\hline$\triangle$ & Fining-upward sequence \\
\hline$s$ & Bioturbation-minor ( 0 to $30 \%$ of surface area) \\
\hline 5,5 & Bioturbation-moderate ( 30 to $60 \%$ of surface area) \\
\hline$s^{5} s$ & Bioturbation - strong ( $>60 \%$ of surface area) \\
\hline$V / / 1$ & Microfaults \\
\hline$\infty \times \infty$ & Burrows \\
\hline - & Pebble \\
\hline
\end{tabular}

Figure 9. Symbols used in the "sedimentary structures" column of the core description form.

in the core: in the graphic representation they are highly flattened or distorted. The same is true for rock fragments or pebbles in the core. The locations of pebbles are shown by solid squares, and the depth of small patches of ash or other lithologically different components is given by a triangular inset of the appropriate lithologic symbol on the right side of the column (Figs. 8 and 10). Prominent beds thinner than $10 \mathrm{~cm}$ are exaggerated in thickness in the lithologic column; less prominent intervals are given in the inset. Voids of less than $10 \mathrm{~cm}$ are not shown.

Smear slide compositions and carbonate content (\% $\mathrm{CaCO}_{3}$ ) determined on board are listed below the core description. The locations of the samples used to make these determinations and the codes used to specify sample type are identified in the column headed "Samples" (Fig. 8). Locations and intervals of interstitial water (IW) samples are shown in the lithology column.

\section{Igneous Rocks}

All igneous rocks were split into working and archive halves with a rock saw. Descriptions are based on visual inspection only (no thin sections were made on board). Each piece is accurately drawn in the "Graphic Representation" column of the core description forms. Two closely spaced horizontal lines indicate the location of the styrofoam spacers taped between the pieces inside the liner. Each piece is numbered sequentially from the top of the section. Spacers are only placed between pieces that do not fit together.

\section{HANDLING OF CORES}

A core is normally cut into $1.5 \mathrm{~m}$ sections, sealed, labeled, and then brought into the shipboard core laboratory for processing. Continuous wet-bulk density determinations are made with the GRAPE before the plastic liner is split. Before the liners are split the cores are left on the rack for several hours for thermal equilibration.

The cores are then split longitudinally into working and archive halves. Samples are taken from the working half, including those used for the determination of sonic velocity (by the Hamilton Frame method), wet-bulk density (by a static GRAPE technique), water content (by gravimetric analysis), calcium-carbonate content (Karbonat Bombe), geochemistry, and paleontology.

Smear slides (or thin sections for lithified sedimentary and igneous rocks) are usually prepared from each major lithology, and slides of most minor lithologies are prepared and examined microscopically. The archive half is then described and photographed: physical disturbances, color, texture, structures, and the composition of the various lithologies are noted on standard core description forms. All raw data are routinely microfilmed, and some are digitized for computer retrieval.

After the cores are sampled and described, they are kept in cold storage on board the Glomar Challenger until they are transferred to the DSDP repository. Sediment sections removed for the study of organic geochemistry are frozen immediately on board and kept frozen. As of this writing (April 1983), all Leg 85 cores are at the DSDP West Coast Repository (Scripps Institution of Oceanography).

\section{NUMBERING OF SITES, HOLES, CORES, AND SAMPLES}

DSDP drill sites are numbered consecutively from the first site drilled by Glomar Challenger in 1968. Site numbers are slightly different from hole numbers. A site number refers to one or more holes drilled while the ship is positioned over one acoustic beacon; these holes can be located within a radius as great as $900 \mathrm{~m}$ from the beacon. Several holes may be drilled at a single site by pulling the drill pipe above the seafloor (above one hole), moving the ship $100 \mathrm{~m}$ or more from the previous hole, and then drilling another hole.

The first (or only) hole drilled at a site takes the site number. A letter suffix distinguishes each additional hole at the same site. Thus, the first hole takes only the site number, the second takes the site number with suffix $\mathrm{A}$, the third takes the site number with suffix B, and so forth. It is important, for sampling purposes, to distinguish between the holes drilled at a site, because the sediments or rocks at a given depth in different holes usually come from different positions in the stratigraphic column. Correlations between cores drilled on Leg 85 are given in Figure 11.

The cored interval is measured in meters below the seafloor. The depth interval of an individual core spans from the depth below seafloor at which the coring began to the depth at which coring ended. The nominal coring interval is $9.5 \mathrm{~m}$ long during rotary drilling and for the VLHPC's long barrel. It is $5 \mathrm{~m}$ for the VLHPC's short barrel. In practice, these coring intervals may be shorter or slightly longer. For example, when we encountered excessive overpull at Site 575, we rerigged the $5 \mathrm{~m}$ VLHPC barrel and washed $5 \mathrm{~m}$, pulling up the corer $2 \mathrm{~m}$ between each core. In this way the corer traveled 


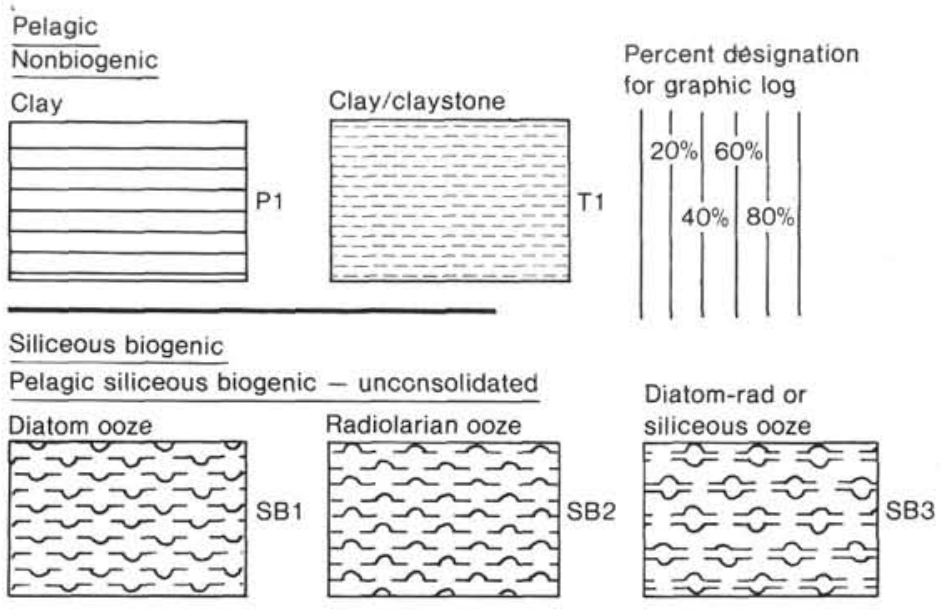

Pelagic siliceous biogenic - strongly indurated

Layers or blebs $<10 \mathrm{~cm}$ thick of
given lithology at the depth
shown by the right tip of the
triangle. The size of the
triangle is independent of the
size of the patch or bleb.

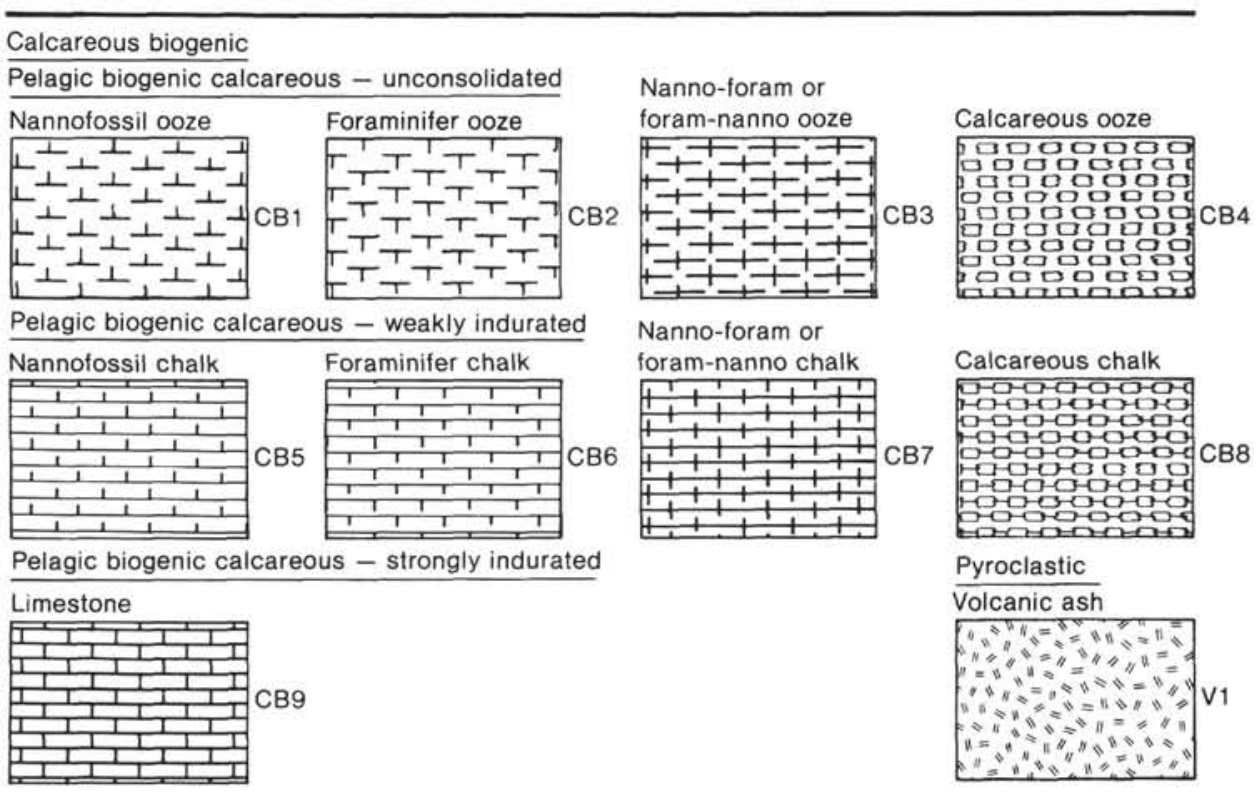

Figure 10. Symbols used in the "graphic lithology" column of the core description form. Acronyms are pattern numbers.

through $2 \mathrm{~m}$ of wash and $3 \mathrm{~m}$ of previously uncored material, collecting, in essence, a $3 \mathrm{~m}$ core.

Cored intervals are not necessarily adjacent to each other, but may be separated by drilled intervals. In soft sediment the drill string can be "washed ahead": that is, the core barrel is in place, but does not recover sediment. This is achieved by pumping water down the pipe at high pressure, which washes the sediment out of the way of the bit, up the space between the drill pipe and the wall of the hole. During this procedure fragments of resistant layers may be caught in the core barrel, so the cored interval may be greater than $9.5 \mathrm{~m}$.
When full, a core normally recovers $9.28 \mathrm{~m}$ of sediment or rock in a plastic liner with a $6.6 \mathrm{~cm}$ inner diameter. In addition, there is about $0.2 \mathrm{~m}$ of sediment or rock (no plastic liner) in the core catcher. With the short barrel of the VLHPC, about $4.75 \mathrm{~m}$ are collected in the liner when it is full, and about $0.2 \mathrm{~m}$ is collected in the core catcher. The core catcher is a device at the bottom of the core barrel that prevents the cored sample from sliding out when the barrel is being retrieved from the hole.

Each core is cut into $1.5 \mathrm{~m}$ long sections, which are numbered serially from the top of the core (Fig. 12). 


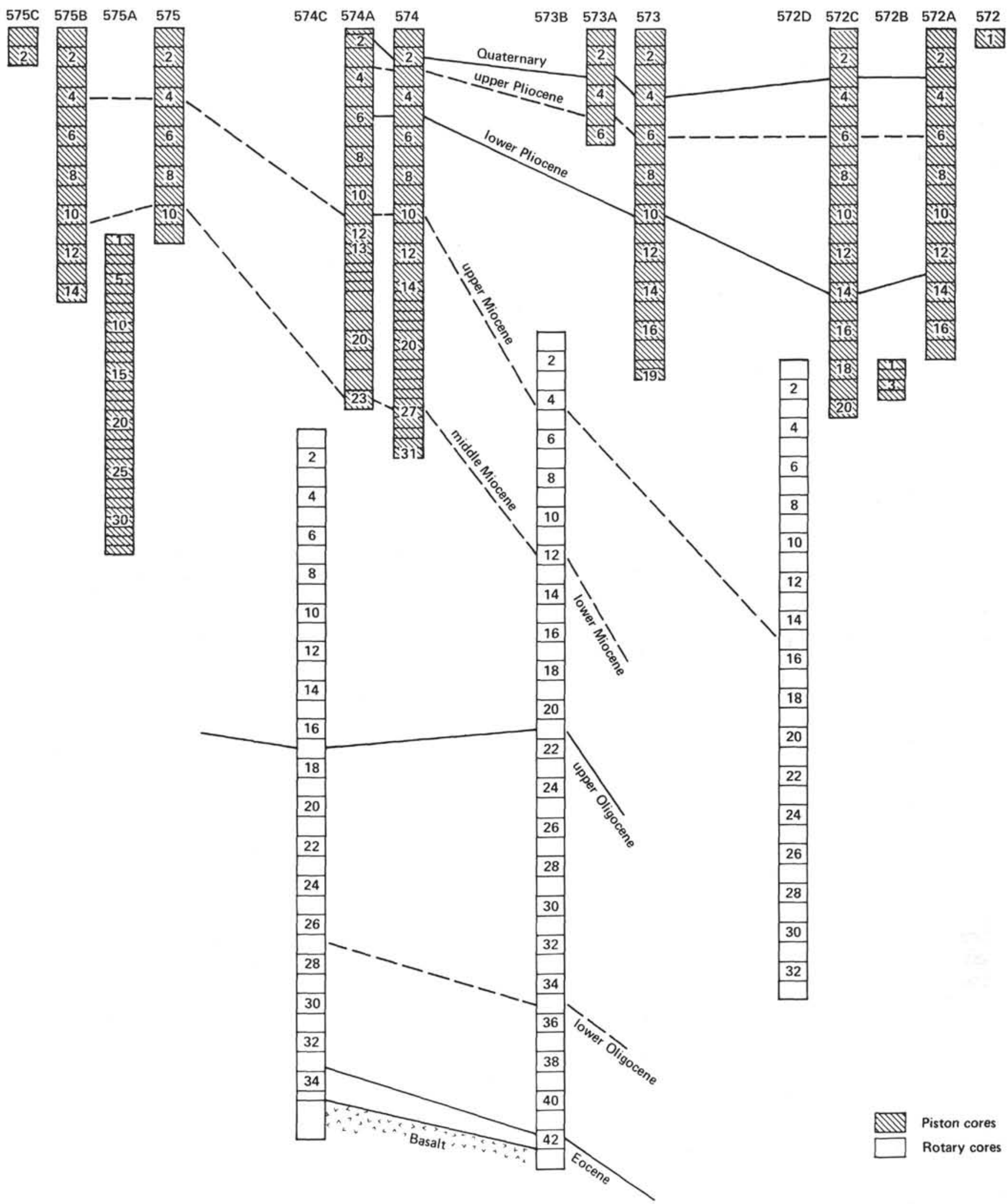

Figure 11. Correlations between the cores recovered on DSDP Leg 85. Solid lines indicate boundaries between time units (e.g., Miocene/Pliocene); dashed lines indicate boundaries between subdivisions of time units (e.g., middle/lower Miocene). Note that the deepest sediments cored in Hole 572D are basal middle Miocene. 

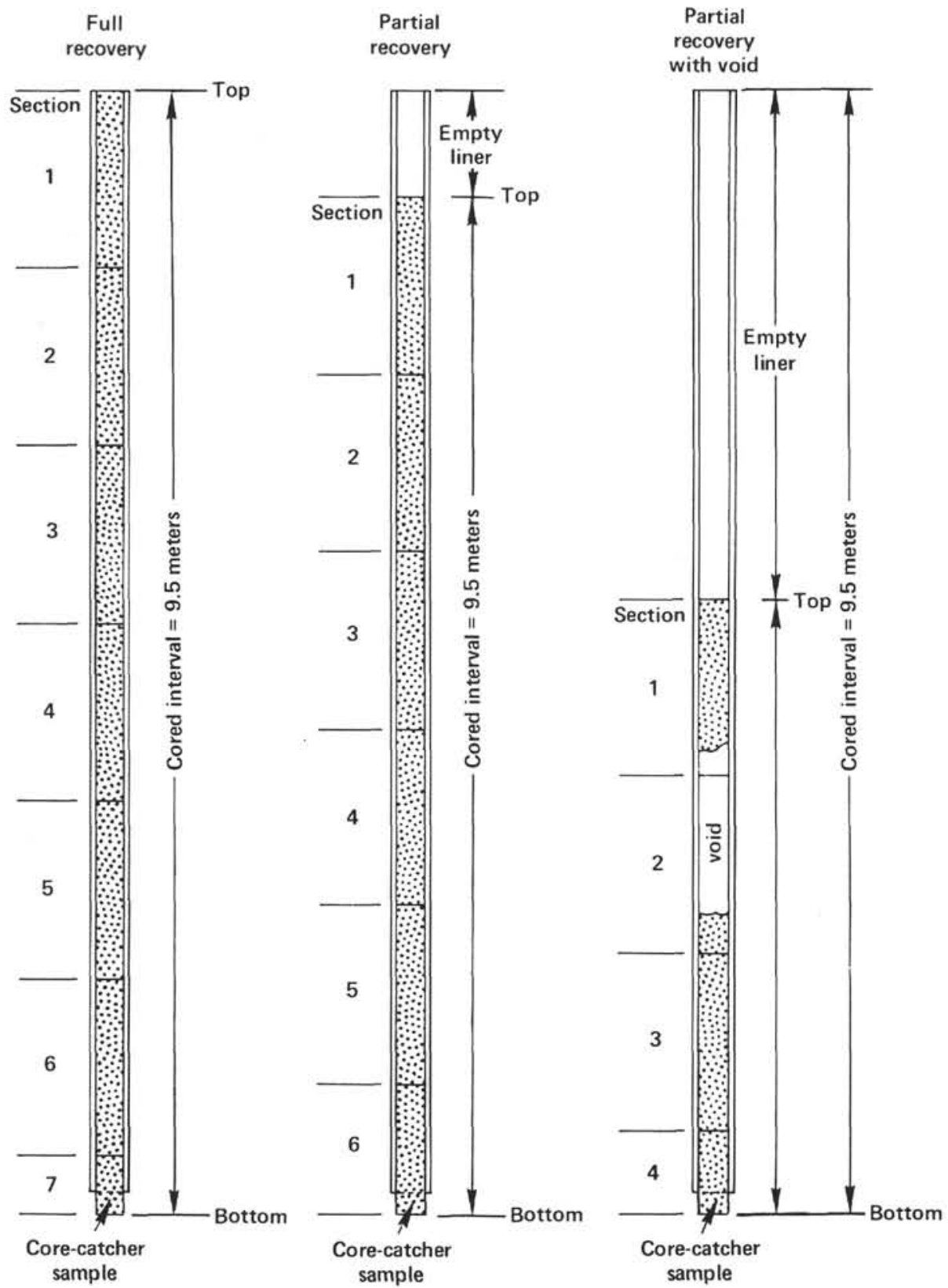

Figure 12. Conventions for cutting and labeling core sections.

When recovery is full, the sections are numbered from 1 through 7 for rotary drilled and long-barrel VLHPC cores, 1 through 4 for short-barrel VLHPC cores. In each case last section is shorter than $1.5 \mathrm{~m}$. The corecatcher sample is placed below the last section when the core is described and labeled core catcher (CC); it is treated as a separate section.

In the case of partial recovery, the original stratigraphic position of the sediment in the cored interval is unknown. If the recovered rocks and sediments are contiguous, the top of this material becomes the top of the cored interval. Section numbering is serial, begins at the top with Section 1 (Fig. 12), and ends when the recovered sediment is accommodated. For example, $4 \mathrm{~m}$ of sediment are divided into three sections-two upper sections $1.5 \mathrm{~m}$ long and one lower section $1 \mathrm{~m}$ long. If the sediment is determined to be discontinuous by the shipboard scientists, sections are divided and numbered serially, but gaps are labeled voids (as in Fig. 12). In igneous sections, voids are marked with spacers.

Cores taken from a hole are numbered serially from the top of the hole downward. The assignment of core numbers and associated depths in meters below the seafloor is usually straightforward, although problems may arise if an interval is cored twice.

Samples are designated by centimeter distances from the top of each section to the top and bottom of the sample in the section. A complete sample number consists of leg-site-hole-core-section, interval in centimeters. For instance, Sample $85-574 C-12-3,12-14 \mathrm{~cm}$ is taken $12-14 \mathrm{~cm}$ from the top of Section 3 of Core 12, from the fourth hole drilled at Site 574 during Leg 85 . A 
sample from the core catcher of this core is designated $85-574 \mathrm{C}-12, \mathrm{CC}$.

\section{OBTAINING SAMPLES}

Investigators who want to obtain samples should refer to the DSDP-NSF Sample Distribution Policy (see the front matter for this volume). Requests must be as specific as possible and include site, core, section, interval within a section, and volume of samples required.

\section{REFERENCES}

Arrhenius, G. O., 1952. Sediment cores from the east Pacific. Rep. Swed. Deep Sea Exped., 1947-1948, 5(3):189-201.

Barron, J. A., Keller, G., Dunn, D. A., Kennett, J. P., Lombari, G. Burckle, L. H., and Vincent, E., in press. A multiple microfossil biochronology for the Miocene. In Kennett, J. P. (Ed.), Cenozoic Paleoceanography Synthesis (CENOP), Mem. Geol. Soc. Am.

Berger, W. H., 1973. Cenozoic sedimentation in the eastern tropical Pacific. Geol. Soc. Am. Bull., 84:1941-1954.

Berggren, W. A., 1983. Correlation of Atlantic, Mediterranean and Indo-Pacific Neogene stratigraphies: geochronology and chronostratigraphy. IGCP Project 114: International Workshop on Pacific Neogene Biostratigraphy (Osaka and Kobe, Japan), November 24-29, 1981.

Berggren, W. A., Benson, R. H., Haq, B. U., Riedel, W. R., Sanfilippo, A., et al., 1976. The El Cuervo section (Andalusia, Spain): micropaleontologic anatomy of an early late Miocene lower bathyal deposit. Mar. Micropaleontol, 1:195-247.

Berggren, W. A., Kent, D. V., and Flynn, J. J., in press. Paleogene geochronology and chronostratigraphy. In Snelling, N. J. (Ed.), Geochronology and the Geological Record, Spec. Pap. Geol. Soc. London.

Blow, W. H., 1969. Late middle Eocene to Recent planktonic foraminiferal biostratigraphy. In Brönniman, P., and Renz, H. H. (Eds.), Proc. First Internat. Conf. Planktonic Microfossils: Leiden (Brill), pp. 199-422.

Boyce, R. E., 1976a. Definitions and laboratory techniques of compressional sound velocity parameters and wet-water content, wetbulk density, and porosity parameters by gravimetric and gamma ray attenuation techniques. In Schlanger, S. O., Jackson, E. D., et al., Init. Repts. DSDP, 33: Washington (U.S. Govt. Printing Office), 931-958.

1976b. Deep Sea Drilling Project procedures for shear strength measurement of clayey sediment using modified Wykeham Farrance Laboratory vane apparatus. In Barker, P. F., Dalziel, I. W. D., et al., Init. Repts. DSDP, 36: Washington (U.S. Govt. Printing Office), 1059-1068.

Bramlette, M. N., 1961. Pelagic sediments. Oceanography: Washington, D.C. (Am. Assoc. Adv. Sci.), pp. 345-366.

Bukry, D., 1975. Coccolith and silicoflagellate stratigraphy, northwestern Pacific Ocean, Deep Sea Drilling Project, Leg 32. In Larson, R. L., Moberly, R., et al., Init. Repts. DSDP, 32: Washington (U.S. Govt. Printing Office), 677-701.

Burckle, L. H., 1972. Late Cenozoic planktonic diatom zones from the eastern equatorial Pacific. Nova Hedwigia Beih., 39:217-246. 1977. Pliocene and Pleistocene diatom datum levels for the equatorial Pacific. Quat. Res., 7:330-340.

1978. Early Miocene to Pliocene datum levels for the equatorial Pacific. Proc. Second Working Group Mtg., IGCP Proj. 114, Biostratigraphic Datum Planes of the Pacific Neogene (Bandung, Indonesia), pp. 25-44.

Burckle, L. W., Hammond, S. R., and Seyb, S. M., 1978. A stratigraphically important new diatom from the Pleistocene of the North Pacific. Pac. Sci., 32:209-214.

Burckle, L. W., and Trainer, J., 1979. Middle and late Pliocene datum levels from the central Pacific. Micropaleontology, 25:281-293.

Casey, R. E., and Reynolds, R. A., 1980. Late Neogene radiolarian biostratigraphy related to magnetostratigraphy and paleoceanography with suggested cosmopolitan radiolarian datums. Spec. Publ. Cushman Found. Foraminiferal Res., 19:287-300.

Dunn, D. A., 1980. Revised techniques for quantitative calcium carbonate analysis using the "Karbonate Bombe," and comparisons to other quantitative analysis methods. J. Sediment. Petrol., 50: 631-637.

Embley, R. W., and Johnson, D. A., 1980. Acoustic stratigraphy and biostratigraphy of Neogene carbonate horizons in the north equatorial Pacific. J. Geophys. Res., 85(B10):5423-5437.

Erickson, A. J., Von Herzen, R. P., Sclater, J. G., Girdler, R. W., Marshall, B. W., and Hyndman, R., 1975. Geothermal measurements in deep-sea drill holes. J. Geophys. Res., 80:2515-2528.

Ewing, J., Ewing, M., Aitkeu, T., and Ludwig, W. J., 1968. North Pacific sediment layers measured by seismic profiling. Am. Geophys. Union Monogr., 12:147-186.

Gartner, S., 1973. Absolute chronology of the late Neogene calcareous nannofossil succession in the equatorial Pacific. Geol. Soc. Am. Bull., 84:2021-2034.

Gealy, E. L., Winterer, E. L., and Moberly, R., 1971. Methods, conventions and general observations. In Winterer, E. L., Riedel, W. R., et al., Init. Repts. DSDP, 7, Pt. 2: Washington (U.S. Govt. Printing Office), 9-26.

Gieskes, J. M., 1973. Interstitial water studies, Leg 15-alkalinity, $\mathrm{pH}, \mathrm{Mg}, \mathrm{Ca}, \mathrm{Si}, \mathrm{PO}_{4}$. In Heezen, B. C., MacGregor, I. D., et al., Init. Repts. DSDP, 20: Washington (U.S. Govt. Printing Office), 813-829.

1974. Interstitial water studies, Leg 25. In Simpson, E. S. W., Schlich, R., et al., Init. Repts. DSDP, 25: Washington (U.S. Govt. Printing Office), 361-394.

Haq, B. U., Worsley, T. R., Burckle, L. H., Douglas, R. G., Keigwin, L. D., Jr., Opdyke, N. D., Savin, S. M., Sommer, M. A., II, Vincent, E., and Woodruff, F., 1980. Late Miocene marine carbonisotope shift and synchroneity of some phytoplanktonic biostratigraphic events. Geology, 8:427-431.

Hays, J. D., 1970. Stratigraphy and evolutionary trends of Radiolaria in North Pacific deep-sea sediments. Mem. Geol. Soc. Am., 126: 185-218.

Hays, J. D., Cook, H. E., III, Jenkins, D. G., Cook, F. M., Fuller, J. T., and Shipboard Scientific Party, 1972. An interpretation of the geologic history of the eastern equatorial Pacific from the drilling results of Glomar Challenger, Leg 9. In Hays, J. D., et al., Init. Repts. DSDP, 9: Washington (U.S. Govt. Printing Office), 909-931.

Hays, J. D., Saito, T., Opdyke, N. D., and Burckle, L. H., 1969. Pliocene-Pleistocene sediments of the equatorial Pacific: their paleomagnetic, biostratigraphic and climatic record. Geol. Soc. Am. Bull., 80:1481-1514.

Henry, K. W., and Opdyke, N. D., 1970. Paleomagnetism of specimens from Leg 3 of the Deep Sea Drilling Project. In Maxwell, A. E., Von Herzen, R., et al., Init. Repts. DSDP, 3: Washington (U.S. Govt. Printing Office), 667-696.

Johnson, D. A., and Knoll, A. H., 1974. Absolute ages of Quaternary radiolarian datum levels in the equatorial Pacific. Quat. Res., 5: 99-110.

Manheim, F. T., and Waterman, L. S., 1974. Diffusimetry (diffusion coefficient estimation) on sediment cores by resistivity probe. In von der Borch, C. C., Sclater, J. G., et al., Init. Repts. DSDP, 22: Washington (U.S. Govt. Printing Office), 633-670.

Mayer, L. A., 1979a. The origin of fine scale acoustic stratigraphy in deep-sea carbonates. J. Geophys. Res., 84(B11):6177-6184. 1979 b. Deep-sea carbonates: acoustic, physical and stratigraphic properties. J. Sediment. Petrol., 49(3):819-836.

Müller, G., and Gastner, M., 1971. The "Karbonat-Bombe," a simple device for the determination of the carbonate content in sediments, soils, and other materials. Neues Jahrb. Mineral. Monatsh., 10: 466-469.

Nigrini, C., 1971. Radiolarian zones in the Quaternary of the equatorial Pacific Ocean. In Funnell, B. M., and Riedel, W. R. (Eds.), The Micropaleontology of the Oceans: Cambridge (Cambridge Univ. Press), pp. 443-461.

Okada, H., and Bukry, D., 1980. Supplementary modification and introduction of code numbers to the low-latitude coccolith biostratigraphic zonation (Bukry, 1973; 1975), Mar. Micropaleontol., 5: 321-325.

Poore, R. Z., Tauxe, L., Percival, S. F., Jr., LaBrecque, J. L., Wright, R., Petersen, N. P., Smith, C. C., Tucker, P., and Hsü, K. J., 1984. Late Cretaceous-Cenozoic magnetostratigraphic and biostratigraphic correlations for the South Atlantic Ocean, Deep Sea Drilling Project Leg 73. In Hsü, K. J., LaBrecque, J. L., et al., In- 
it. Repts. DSDP, 73: Washington (U.S. Govt. Printing Office), 645-656.

Prell, W. L., Gardner, J. V., et al., 1982. Init. Repts. DSDP, 68: Washington (U.S. Govt. Printing Office).

Riedel, W. R., and Funnell, B. M., 1964. Tertiary sediment cores and microfossils from the Pacific Ocean floor. Q. J. Geol. Soc. London, 120:305-368.

Riedel, W. R., and Sanfilippo, A., 1978. Stratigraphy and evolution of tropical Cenozoic radiolarians. Micropaleontology, 23:61-96.

Ryan, W. B. F., Cita, M. B., Dreyfuss, R. M., et al., 1974. A paleomagnetic assignment of Neogene stage boundaries and the development of synchronous datum planes between the Mediterranean, the Pacific and Indian oceans in order to investigate the response of the world oceans to the Mediterranean Salinity Crisis. Riv. Ital. Paleontol., 80:631-688.

Saito, T., Burckle, L. H., and Hays, J. D., 1975. Late Miocene to Pleistocene biostratigraphy of equatorial Pacific sediments. In Saito, T., and Burckle, L. H. (Eds.), Late Neogene Epoch Boundaries: New York (Micropaleontology Press), pp. 226-244.

Theyer, F., Mato, C. Y., and Hammond, B. R., 1978. Paleomagnetic and geochronologic calibration of latest Oligocene to Pliocene radiolarian events, equatorial Pacific. Mar. Micropaleontol., 3: 377-395.

Thierstein, H. R., Geitzenauer, K., Molfino, B., et al., 1977. Global synchroneity of late Quaternary coccolith datums: validation by oxygen isotopes. Geology, 5:400-404.

Thompson, P. R., 1976. Planktonic foraminiferal dissolution and the progress towards a Pleistocene equatorial Pacific transfer function. J. Foraminiferal Res., 6:208-277.
Uyeda, S., and Horai, K., 1982. Heat flow measurements on Deep Sea Drilling Project Leg 60. In Hussong, D. M., Uyeda, S., et al., Init. Repts. DSDP, 60: Washington (U.S. Govt. Printing Office), 789-800.

van Andel, T. H., Heath, G. R., and Moore, T. C., Jr., 1975. Cenozoic history and paleoceanography of the central equatorial Pacific. Mem. Geol. Soc. Am. 143.

Van Couvering, J. A., and Berggren, W. A., 1977. Biostratigraphic basis of the Neogene time scale. In Kaufmann, E. G., and Hazel, J. E. (Eds.), Concepts and Methods in Biostratigraphy: Stroudsburg, PA (Dowden, Hutchinson, Ross), pp. 283-306.

Vincent, E. S., 1981. Neogene stratigraphy of Hess Rise (central North Pacific) and paleoceanographic implications. In Thiede, J., Vallier, T. L., et al., Init. Repts. DSDP, 62: Washington (U.S. Govt. Printing Office), 571-606.

Von Herzen, R. P., and Maxwell, A. E., 1959. The measurement of thermal conductivity of deep-sea sediments by a needle probe method. J. Geophys. Res., 64:1557-1563.

von Rad, U., Ryan, W. B. F., et al., 1979. Init. Repts. DSDP, 47, Pt. 1: Washington (U.S. Govt. Printing Office).

Wentworth, C. K., 1922. A scale of grade and class terms of clastic sediments. J. Geol., 30:377-392.

Winterer, E. L., 1973. Sedimentary facies and plate tectonics of the equatorial Pacific. Am. Assoc. Pet. Geol. Bull., 57:265-282.

Date of Initial Receipt: 29 April 1983

Date of Acceptance: 1 July 1983

Table 1. Biodatums used to calculate accumulation rates for Leg 85 sites.

\begin{tabular}{|c|c|c|c|}
\hline Fossil group ${ }^{a}$ & Datum $^{b}$ & $\begin{array}{l}\text { Age } \\
(\mathrm{Ma})^{\mathrm{c}}\end{array}$ & References \\
\hline $\mathrm{F}$ & T Globigerina pseudofoliata & 0.2 & Saito et al. (1975) \\
\hline $\mathbf{R}$ & B Buccinosphaera invaginata & 0.3 & $\begin{array}{l}\text { Johnson and Knoll } \\
\text { (1974) }\end{array}$ \\
\hline $\mathbf{R}$ & T Stylatractus universus & 0.44 & Hays \\
\hline $\mathrm{N}$ & T Pseudoemiliania lacunosa & 0.47 & Thierstein et al. (1977) \\
\hline $\mathrm{F}$ & T Globorotalia tosaensis & 0.6 & Thompson (1976) \\
\hline D & T Nitzschia reinholdii & 0.65 & Burckle (1977) \\
\hline D & T Rhizosolenia matuyamai & 0.93 & Burckle et al. (1978) \\
\hline D & B Rhizosolenia matuyamai & 1.0 & Burckle et al. (1978) \\
\hline $\mathbf{R}$ & T Anthocyrtidium angulare & 1.1 & $\begin{array}{l}\text { Johnson and Knoll } \\
\text { (1974) }\end{array}$ \\
\hline $\mathbf{R}$ & T Lamprocyrtis neoheteroporos & 1.15 & $\begin{array}{l}\text { Johnson and Knoll } \\
\text { (1974) }\end{array}$ \\
\hline $\mathrm{F}$ & T Pulleniatina finalis & 1.3 & Saito et al. (1975) \\
\hline $\mathbf{R}$ & B Theocorythium trachelium & 1.35 & $\begin{array}{l}\text { Johnson and Knoll } \\
\text { (1974) }\end{array}$ \\
\hline $\mathbf{R}$ & T Pterocanium prismatium & 1.5 & Theyer et al. (1978) \\
\hline D & T Rhizosolenia praebergonii robusta & 1.55 & Burckle (1977) \\
\hline $\mathrm{F}$ & T Globigerinoides fistulosus & 1.6 & Saito et al. (1975) \\
\hline $\mathrm{F}$ & T Globigerinoides obliquus & 1.7 & Saito et al. (1975) \\
\hline D & B Pseudoeunotia doliolus & 1.8 & Burckle (1977) \\
\hline $\mathrm{F}$ & B Globorotalia truncatulinoides & 1.9 & Saito et al. (1975) \\
\hline $\mathbf{R}$ & T Lamprocyclas heteroporos & 2.0 & Hays (1970) \\
\hline D & T Thalassiosira convexa & 2.1 & $\begin{array}{l}\text { Burckle and Trainer } \\
\text { (1979) }\end{array}$ \\
\hline $\mathbf{R}$ & T Stichocorys peregrina & 2.4 & Theyer et al. (1978) \\
\hline $\mathrm{D}$ & T Nitzschia jouseae & 2.6 & $\begin{array}{l}\text { Burckle and Trainer } \\
\text { (1979) }\end{array}$ \\
\hline $\mathrm{F}$ & T Globoquadrina altispira & 2.9 & Hays et al. (1969) \\
\hline D & B Rhizosolenia praebergonii & 3.0 & $\begin{array}{l}\text { Burckle and Trainer } \\
\text { (1979) }\end{array}$ \\
\hline $\mathrm{F}$ & T Sphaeroidinellopsis seminulina & 3.05 & $\begin{array}{l}\text { Saito et al. (1975), } \\
\text { Hays et al. (1969) }\end{array}$ \\
\hline $\mathrm{F}$ & B Globorotalia tosaensis & 3.2 & Hays et al. (1969) \\
\hline $\mathbf{R}$ & T Spongaster pentas & 3.4 & Theyer et al. (1978) \\
\hline $\mathrm{F}$ & T Globorotalia margaritae & 3.4 & $\begin{array}{l}\text { Saito et al. (1975), } \\
\text { Hays et al. (1969) }\end{array}$ \\
\hline D & B Thalassiosira convexa convexa & 3.6 & $\begin{array}{l}\text { Burckle and Trainer } \\
\text { (1979) }\end{array}$ \\
\hline $\mathrm{R}$ & B Spongaster tetras & 3.6 & Theyer et al. (1978) \\
\hline $\mathrm{R}$ & $\mathrm{T}$ Didymocyrtis penultima & 3.69 & Theyer et al. (1978) \\
\hline $\mathrm{F}$ & T Globigerina nepenthes & 3.85 & $\begin{array}{l}\text { Saito et al. (1975), } \\
\text { Hays et al. (1969) }\end{array}$ \\
\hline
\end{tabular}


Table 1. (Continued).

\begin{tabular}{|c|c|c|c|}
\hline Fossil group ${ }^{a}$ & Datum $^{b}$ & $\begin{array}{l}\text { Age } \\
(\mathrm{Ma})^{\mathrm{c}}\end{array}$ & References \\
\hline D & B Asteromphalus elegans & 3.9 & Burckle (1978) \\
\hline $\mathrm{R}$ & B Lamprocyclas heteroporos & 4.3 & $\begin{array}{l}\text { Casey and Reynolds } \\
(1980)\end{array}$ \\
\hline $\mathbf{R}$ & B Spongaster pentas & 4.3 & Theyer et al. (1978) \\
\hline D & T Nitzschia cylindrica & 4.35 & $\begin{array}{l}\text { Burckle (pers. comm., } \\
\text { 1983) }\end{array}$ \\
\hline D & B Nitzschia jouseae & 4.5 & Burckle (1978) \\
\hline $\mathrm{N}$ & B Ceratolithus rugosus & 4.75 & Burckle (1978) \\
\hline $\mathbf{R}$ & B Pterocanium prismatium & 4.8 & Theyer et al. (1978) \\
\hline $\mathrm{F}$ & B Sphaeroidinella dehiscens & 5.0 & Saito et al. (1975) \\
\hline $\mathbf{R}$ & T Acrobotrys tritubus & 5.0 & Theyer et al. (1978) \\
\hline D & T Thalassiosira miocenica & 5.05 & Burckle (1978) \\
\hline $\mathrm{F}$ & B Globorotalia tumida & 5.2 & Saito et al. (1975) \\
\hline $\mathrm{F}$ & T Globoquadrina dehiscens & 5.4 & Saito et al. (1975) \\
\hline D & T Asterolampra acutiloba & 5.4 & Burckle (1978) \\
\hline $\mathrm{N}$ & B Ceratolithus acutus & 5.65 & Gartner (1973) \\
\hline D & T Nitzschia miocenica & 5.7 & Burckle (1978) \\
\hline D & T Thalassiosira praeconvexa & 5.9 & Burckle (1978) \\
\hline $\mathrm{F}$ & B Globorotalia margaritae & 6.0 & Saito et al. (1975) \\
\hline D & B Thalassiosira convexa var. aspinosa & 6.15 & Burckle (1978) \\
\hline D & B Thalassiosira miocenica & 6.15 & Burckle (1978) \\
\hline $\mathrm{F}$ & B Pulleniatina primalis & 6.2 & Saito et al. (1975) \\
\hline D & B Thalassiosira praeconvexa & 6.4 & Burckle (1978) \\
\hline $\mathbf{R}$ & B Stichocorys peregrina & 6.4 & Theyer et al. (1978) \\
\hline $\mathrm{R}$ & B Solenosphaera omnitubus & 6.6 & Theyer et al. (1978) \\
\hline D & B Nitzschia miocenica & 7.4 & Burckle (1978) \\
\hline $\mathrm{D}$ & T Rossiella paleacea & 7.5 & Burckle (1978) \\
\hline $\mathrm{N}$ & B Discoaster quinqueramus & 7.6 & Gartner (1973) \\
\hline D & T Thalassiosira burckliana & 7.9 & Burckle (1978) \\
\hline $\mathbf{R}$ & B Didymocyrtis penultima & 8.2 & Theyer et al. (1978) \\
\hline $\mathrm{R}$ & T Diartus hughesi & 8.2 & Theyer et al. (1978) \\
\hline D & T Coscinodiscus yabei & 8.6 & Burckle (1978) \\
\hline D & B Thalassiosira burckliana & 9.2 & Burckle (1978) \\
\hline $\mathrm{R}$ & T Diartus petterssoni & 9.7 & Theyer et al. (1978) \\
\hline $\mathrm{F}$ & B Neogloboquadrina acostaensis & 10.8 & Ryan et al. (1974) \\
\hline $\mathrm{N}$ & T Discoaster hamatus & 11.1 & Burckle (1978) \\
\hline D & $\begin{array}{l}\text { B Coscinodiscus vetustissimus } \\
\text { javanica }\end{array}$ & 11.1 & Burckle (1978) \\
\hline $\mathbf{R}$ & B Acrobotrys tritubus & 11.2 & Theyer et al. (1978) \\
\hline D & T Actinocyclus ellipticus moronensis & 11.4 & Burckle (1978) \\
\hline $\mathbf{R}$ & B Didymocyrtis antepenultima & 11.5 & Theyer et al. (1978) \\
\hline $\mathbf{R}$ & B Diartus hughesi & 11.5 & Theyer et al. (1978) \\
\hline R & T Stichocorys wolffii & 11.6 & Theyer et al. (1978) \\
\hline $\mathbf{R}$ & T Cyrtocapsella cornuta & 11.8 & Theyer et al. (1978) \\
\hline $\mathbf{R}$ & T Dorcadospyris alata & 11.8 & Theyer et al. (1978) \\
\hline $\mathrm{F}$ & T Turborotalia mayeri & 12.0 & Ryan et al. (1974) \\
\hline D & T Coscinodiscus tuberculatus & 12.0 & Burckle (1978) \\
\hline D & T Denticula punctata hustedtii & 12.2 & Burckle (1978) \\
\hline $\mathbf{R}$ & B Diartus petterssoni & 12.3 & Theyer et al. (1978) \\
\hline D & T Craspedodiscus coscinodiscus & 12.3 & Burckle (1978) \\
\hline $\mathbf{R}$ & T Cyrtocapsella tetrapera & 12.5 & Theyer et al. (1978) \\
\hline $\mathrm{F}$ & B Globigerina nepenthes & 12.7 & Ryan et al. (1974) \\
\hline D & B Hemidiscus cuneiformis & 12.7 & Burckle (1978) \\
\hline D & T Denticulopsis nicobarica & 13.1 & Burckle (1978) \\
\hline D & T Coscinodiscus lewisianus & 13.8 & Burckle (1978) \\
\hline $\mathrm{R}$ & B Didymocyrtis laticonus & 13.8 & Theyer et al. (1978) \\
\hline R & B Lithopera neotera & 14.2 & Theyer et al. (1978) \\
\hline D & T Cestodiscus peplum & 14.3 & Burckle (1978) \\
\hline D & B Coscinodiscus tuberculatus & 14.4 & Burckle (1978) \\
\hline $\mathbf{R}$ & T Calocycletta virginis & 14.8 & Theyer et al. (1978) \\
\hline D & T Annellus californicus & 15.0 & Burckle (1978) \\
\hline $\mathrm{R}$ & T Calocycletta costata & 15.4 & Theyer et al. (1978) \\
\hline $\mathrm{R}$ & B Dorcadospyris alata & 15.7 & Theyer et al. (1978) \\
\hline $\mathbf{R}$ & T Dorcadospyris dentata & 15.8 & Theyer et al. (1978) \\
\hline $\mathrm{R}$ & T Didymocyrtis prismatica & 15.8 & Barron et al. (in press) \\
\hline $\mathrm{R}$ & T Lychnocanoma elongata & 15.9 & Barron et al. (in press) \\
\hline $\mathrm{D}$ & T Thalassiosira fraga & 16.2 & Barron et al. (in press) \\
\hline $\mathrm{R}$ & B Calocycletia costata & 16.8 & Theyer et al. (1978) \\
\hline $\mathrm{R}$ & B Dorcadospyris dentata & 17.1 & Theyer et al. (1978) \\
\hline D & B Denticulopsis nicobarica & 18.0 & Barron et al. (in press) \\
\hline $\mathbf{R}$ & B Stichocorys wolffii & 18.9 & Barron et al. (in press) \\
\hline $\mathbf{R}$ & T Dorcadospyris aleuchus & 19,7 & Theyer et al. (1978) \\
\hline D & T Bogorovia veniamini & 19.9 & $\begin{array}{l}\text { Burckle (pers. comm., } \\
\text { 1982) }\end{array}$ \\
\hline $\mathbf{R}$ & B Cyclampterium leptetrum & 20.0 & Theyer et al. (1978) \\
\hline $\mathrm{R}$ & B Didymocyrtis siolina & 20.2 & Theyer et al. (1978) \\
\hline $\mathrm{R}$ & B Stichocorys delmontensis & 21.1 & Barron et al. (in press) \\
\hline
\end{tabular}


Table 1. (Continued).

\begin{tabular}{clcl}
\hline Fossil group $^{\text {a }}{ }^{-1}$ & \multicolumn{1}{c}{ Datum $^{\text {b }}$} & $\begin{array}{c}\text { Age } \\
(\mathrm{Mac})^{\mathrm{c}}\end{array}$ & \multicolumn{1}{c}{ References } \\
\hline R & T Theocyrtis annosa & 21.3 & Thryer et al. (1978) \\
R & B Calocycletta virginis & 21.4 & Theyer et al. (1978) \\
N & T Triquetrorhabdulus carinatus & 21.8 & Theyer (unpubl. data) \\
R & B Cyrtocapsella corruta & 22.2 & Barron et al. (in press) \\
R & T Cyrtocapsella tetrapera & 22.2 & Barron et al. (in press) \\
R & T Dorcadospyris papilio & 22.6 & Barron et al. (in press) \\
R & T Artophormis gracilis & 22.6 & Barron et al. (in press) \\
N & B Discoaster druggi & 22.8 & Theyer (unpubl. data) \\
N & T Sphenolithus ciperoensis & 23.7 & Poore et al. (1984) \\
F & B Globigerapsis kugleri & 23.7 & Poore et al. (1984) \\
R & B Dorcadospyris praeforcipata & 25.7 & Theyer (unpubl. data) \\
R & B Lychnocanoma elongata & 25.9 & Theyer et al. (1978) \\
N & T Sphenolithus distentus & 26.7 & Theyer (unpubl. data) \\
F & T Globorotalia opima & 28.3 & Poore et al. (1984) \\
N & B Sphenolithus ciperoensis & 30.2 & Poore et al. (1984) \\
N & T Sphenolithus pseudoradians & 31.0 & Poore et al. (1984) \\
R & B Dorcadospyris papilio & 31.6 & Theyer (unpubl. data) \\
N & B Sphenolithus distentus & 34.1 & Poore et al. (1984) \\
R & B Dorcadospyris ateuchus & 34.4 & Theyer (unpubl. data) \\
N & T Reticulofenestra hillae & 34.7 & Poore et al. (1984) \\
N & T Reticulofenestra umbilica & 34.7 & Poore et al. (1984) \\
N & T Cyclococcolithina formosa & 35.1 & Poore et al. (1984) \\
R & B Artophormis gracilis & 36.3 & Theyer (unpubl. data) \\
F & T Turborotalia cerroazulensis & 36.3 & Poore et al. (1984) \\
N & T Discoaster barbadiensis & 36.8 & Poore et al. (1984) \\
N & T Discoaster saipanensis & 36.8 & Poore et al. (1984) \\
\hline
\end{tabular}

${ }^{\mathrm{a}} \mathrm{F}=$ foraminifers, $\mathrm{R}=$ radiolarians, $\mathrm{N}=$ nannofossils, $\mathrm{D}=$ diatoms.

${ }^{b} \mathrm{~T}=$ top of range, $\mathrm{B}=$ bottom of range.

c Ages follow an interim (unpublished) time scale of Berggren et al., widely circulated in 1983. This time scale is similar to a revised scale now in press (Berggren, in press), except that in the later version Anomaly 5 is correlated with Chron 11 instead of Chron 9. See Barron et al. (this volume) for the updated time scale. 